\title{
Effects of 1-Methylcyclopropene and Naphthaleneacetic Acid on Fruit Set and Expression of Genes Related to Ethylene Biosynthesis and Perception and Cell Wall Degradation in Apple
}

\author{
Hong Zhu and Rongcai Yuan ${ }^{1}$ \\ Alson H. Smith, Jr. Agricultural Research and Extension Center, Virginia Polytechnic Institute and \\ State University, 595 Laurel Grove Road, Winchester, VA 22602 \\ Duane W. Greene ${ }^{2}$ \\ Department of Plant, Soil, and Insect Sciences, University of Massachusetts, Amherst, MA 01003 \\ Eric P. Beers \\ Department of Horticulture, Virginia Polytechnic Institute and State University, Blacksburg, \\ VA 24061
}

\begin{abstract}
AdDitional INDEX words. 1-MCP, ethylene receptor, Malus $\times$ domestica, NAA, polygalacturonase, abscission
ABstract. The effects of 1-methylcyclopropene (1-MCP) and naphthaleneacetic acid (NAA) on fruit set and the expression of genes related to ethylene biosynthesis and perception and cell wall degradation in apple (Malus $\times$ domestica Borkh.) were studied when applied during the normal chemical thinning period. 1-MCP at $209 \mathrm{mg} \cdot \mathrm{L}^{-1} \mathrm{had}$ a small negative effect or no effect on the final fruit set, depending on the experiment, but could cause a transient delay of June drop when applied at petal fall or the $10-\mathrm{mm}$ stage in 'Pioneer McIntosh' apple. 1-MCP at $160 \mathrm{mg} \cdot \mathrm{L}^{-1} \mathrm{had}$ no effect on fruit abscission but induced ethylene production by leaves and fruit of 'Golden Delicious' apple. NAA at 6 or $15 \mathrm{mg} \cdot \mathrm{L}^{-1}$ effectively increased fruit abscission in both apple cultivars. NAA enhanced the expression of genes related to ethylene biosynthesis (MdACS5A, MdACS5B, and MdACO1) or perception (MdETR1, MdETR1b, MdETR2, MdERS1, and MdERS2) and cell wall degradation (MdPG2). 1-MCP did not affect the expression of MdACS5A and $M d A C S 5 B$ in the fruit abscission zone (FAZ), although it enhanced the expression of these two genes in the fruit cortex (FC) from 6 hours to 1 day after treatment. The expression of MdACO1 in both tissues was increased by 1-MCP by 3 days post-treatment and thereafter. 1-MCP had only a small influence on the expression of most ethylene receptor genes, with the exception of MdETR1, which was upregulated in the FC to a level similar to that observed for NAA treatment. In response to 1-MCP, in the FAZ, the expression of $M d C e l 1$ and $M d P G 2$ was upregulated at the beginning and the end, respectively, of the experiment, but otherwise remained at or below control levels. 1-MCP did not inhibit NAA-induced abscission of young apple fruit, suggesting that abscission does not solely depend on ethylene signal transduction, or that the periods of effectiveness for 1-MCP and ethylene were asynchronous.
\end{abstract}

Ethylene is involved in young apple fruit abscission (Curry, 1991; Dal Cin et al., 2005; McArtney, 2002; Zhu et al., 2008). Application of ethephon, an ethylene-releasing compound, effectively promoted the abscission of young fruit in apple (Walsh et al., 1979; Yuan, 2007), while aminoethoxyvinylglycine (AVG), an inhibitor of ethylene biosynthesis, reduced fruit ethylene production and the abscission of young fruit in apple (Williams and Flook, 1980; Zhu et al., 2008). Increased abscission of young apple fruit caused by the chemical thinner naphthaleneacetic acid (NAA) is linked with increased ethylene production; hence, NAA may act in part through ethylene signaling (Curry, 1991; Zhu et al., 2008).

The pathway of ethylene synthesis has been well established in higher plants. Ethylene is formed from methionine via

Received for publication 14 June 2010. Accepted for publication 6 July 2010. We gratefully acknowledge the financial support from the Virginia Agricultural Council and Rohm and Haas Company and the assistance of David H. Carbaugh and Grace Engelman.

${ }^{1}$ This paper is dedicated to the memory of Rongcai Yuan. He was a devoted plant scientist, revered colleague and a kind and patient mentor. He is greatly missed by those who were privileged to know him.

${ }^{2}$ Corresponding author. E-mail: dgreene@pssci.umass.edu.
S-adenosyl-L-methionine (SAM) and 1-aminocyclopropane1-carboxylic acid (ACC) (Yang and Hoffman, 1984). The conversions of SAM to ACC and ACC to ethylene are the two committed steps in ethylene biosynthesis, and are catalyzed by ACC synthase (ACS) and ACC oxidase (ACO), respectively (Alexander and Grierson, 2002). AVG is a competitive inhibitor of ACS and other members of the class of pyridoxal-5' phosphate-dependent enzymes (Huai et al., 2001). Thus far, five ACS genes and one ACO gene have been isolated and characterized (Dal Cin et al., 2005; Li and Yuan, 2008) in apple. It has been reported that $M d A C S 1$ and $M d A C O 1$ are related to the increase in fruit ethylene during fruit ripening, whereas $M d A C S 5 A, M d A C S 5 B$, and $M d A C O 1$ are associated with ethylene production by young fruit ( $\mathrm{Li}$ and Yuan, 2008).

Ethylene is perceived by a series of receptors that undergo conformational changes upon ethylene binding and then inactivate the Raf-like serine/threonine kinase CTR1, a negative regulator in ethylene signal transduction. This relieves the repression on downstream signaling components, thus allowing for activation of the EIN3/EIL transcription factors and ethylene-inducible genes, which control a myriad of ethyleneassociated plant growth and development processes (Chang and 
Bleecker, 2004; Chen et al., 2005). Six ethylene receptors have been identified in tomato [Solanum lycopersicum L. (Bleecker, 1999)] and five have been isolated and characterized in apple (Dal Cin et al., 2005; Li and Yuan, 2008). Among the ethyleneinducible transcriptional cascade are the genes for hydrolases such as $\beta$-1,4-glucanase (cellulase or EG) and polygalacturonase (PG), which are induced in the fruit abscission zone where they catalyze the breakdown of the middle lamellae and cell walls and promote fruit drop (Bonghi et al., 2000; Ward et al., 1999).

1-Methylcyclopropene (1-MCP), a gaseous inhibitor of ethylene action, has been used to delay postharvest ripening of climacteric fruit such as apple (Fan et al., 1999; Sisler and Serek, 1997), peach [Prunus persica L. (Kluge and Jacomino, 2002)], avocado [Persea americana Mill. (Jeong et al., 2002)], and mango [Mangifera indica L. (Jiang and Joyce, 2000)]. 1-MCP also delayed leaf abscission in sweet orange [Citrus sinensis L. (Zhong et al., 2001)] and mature fruit abscission in apple (Li and Yuan, 2008; Yuan and Carbaugh, 2007; Yuan and $\mathrm{Li}, 2008$ ), and has been widely used in the cut flower industry (Blankenship and Dole, 2003). 1-MCP has been formulated as a stable powder that releases the active gaseous form when mixed with water. Recently, a sprayable formulation of $1-\mathrm{MCP}$ became available for experimental use in the field.

The purposes of the present work were to study the effect of a sprayable formulation of 1-MCP on apple fruit set and the effects of 1-MCP and NAA on the expression of genes related to ethylene biosynthesis, perception, and cell wall degradation.

\section{Materials and Methods}

Expt. 1: 'Pioneer McIntosh'/M.9, Belchertown, MA. Twenty 18-year-old 'Pioneer McIntosh' apple trees were selected in a non-irrigated block at the University of Massachusetts Horticultural Research Center in 2007. Trees were trained as a central leader and were cared for using normal industry accepted culture and pest management practices. At the pink stage of flower development, two representative limbs per tree were randomly selected and tagged and their circumferences were measured. After counting all blossom clusters on the selected limbs, blossom cluster density was calculated by dividing the number of blossom clusters by the square centimeter of limb cross-sectional area (LCSA). Trees were placed into five groups (replications) based upon similarity in the calculated blossom cluster density. Treatments were randomly assigned among the four trees within each replication. Treatments were sprayable 1-MCP (Rohm and Haas Company, Spring House, PA) applied at three distinct physiological stages: bloom (10 May), petal fall (17 May), and 10-mm-diameter fruit (24 May). One tree in each replication was not sprayed and served as the untreated control. The sprayable formulation of 1-MCP was applied as a dilute handgun application using an 11.4-L backpack sprayer propelled with $\mathrm{CO}_{2}$ at $276 \mathrm{KPa}$ pressure. In the backpack sprayer, $62.5 \mathrm{~g}$ of $1-\mathrm{MCP}$ was placed along with $113.5 \mathrm{~mL}$ of summer oil (AFxDR-038, Rohm and Hass) and $6 \mathrm{~mL}$ of silicone surfactant (Silwet L-77; Helena Chemical Co., Memphis, TN). This gave a final 1-MCP concentration in the tank of $209 \mathrm{mg} \cdot \mathrm{L}^{-1}$ with $1 \%$ oil and $0.05 \%$ Silwet L-77. The sprayable 1-MCP was mixed in the orchard. The sprayer was filled with water and then silicone surfactant and summer oil were added and mixed using a portable drill equipped with an attached paint mixer. The
Table 1. Effect of 1-methylcyclopropene (1-MCP) application at different physiological stages on fruit set of 'Pioneer McIntosh'/ M.9 apple.

\begin{tabular}{|c|c|c|c|c|}
\hline \multicolumn{2}{|c|}{ 1-MCP application ${ }^{\mathrm{z}}$} & \multirow{2}{*}{$\begin{array}{c}\text { Bloom } \\
\text { Blossom clusters } \\
\left(\text { no. } / \mathrm{cm}^{2} \text { LCSA) }\right)^{y}\end{array}$} & \multicolumn{2}{|l|}{ Fruit set } \\
\hline Stage & Date & & (no. $/ \mathrm{cm}^{2}$ LCSA) & $(\%)$ \\
\hline Control & - & $9.9 \mathrm{a}^{\mathrm{x}}$ & $11.0 \mathrm{a}$ & $\overline{109 \mathrm{a}}$ \\
\hline Bloom & 10 May & $9.9 \mathrm{a}$ & $10.1 \mathrm{a}$ & $108 \mathrm{a}$ \\
\hline Petal fall & 17 May & $9.9 \mathrm{a}$ & $12.3 \mathrm{a}$ & 129 \\
\hline $10 \mathrm{~mm}$ & 24 May & $9.8 \mathrm{a}$ & $10.0 \mathrm{a}$ & 103 \\
\hline Significance & & & & \\
\hline Treatment & & NS & NS & NS \\
\hline
\end{tabular}

${ }^{\mathrm{z}} 1-\mathrm{MCP}$ was applied with a $\mathrm{CO}_{2}$ back-pack sprayer at $209 \mathrm{mg} \cdot \mathrm{L}^{-1}$ in 1\% summer oil (AFxRD-038; Rohm and Hass, Spring House, PA) and $0.05 \%$ silicone surfactant (Silwet L-77; Helena Chemical Co., Memphis, TN).

${ }^{\mathrm{y}} \mathrm{LCSA}=$ limb cross-sectional area.

${ }^{x}$ Mean separation by Duncan's multiple range test at $P \leq 0.05$.

${ }^{\mathrm{NS}}$ Not significant.

Table 2. Effect of 1-methylcyclopropene (1-MCP) application at different physiological stages on fruit set of individually tagged spurs on 'Pioneer McIntosh'/M.9 apple.

\begin{tabular}{|c|c|c|c|c|c|}
\hline \multicolumn{2}{|c|}{ 1-MCP application ${ }^{\mathrm{z}}$} & \multicolumn{4}{|c|}{ Fruit (no./spur) } \\
\hline Stage & Date & 29 May & 6 June & 13 June & 14 Aug. \\
\hline Control & - & $3.4 b^{y}$ & $2.7 \mathrm{a}$ & $1.9 \mathrm{a}$ & $1.5 \mathrm{a}$ \\
\hline Bloom & 10 May & $3.3 \mathrm{~b}$ & $2.6 \mathrm{a}$ & $1.9 \mathrm{a}$ & $1.5 \mathrm{a}$ \\
\hline Petal fall & 17 May & $4.0 \mathrm{a}$ & $2.8 \mathrm{a}$ & $2.1 \mathrm{a}$ & $1.6 \mathrm{a}$ \\
\hline $10 \mathrm{~mm}$ & 24 May & $4.5 \mathrm{a}$ & $2.7 \mathrm{a}$ & $2.0 \mathrm{a}$ & $1.6 \mathrm{a}$ \\
\hline Significance & & & & & \\
\hline Treatment & & $* *$ & NS & NS & NS \\
\hline
\end{tabular}

${ }^{\mathrm{z}} 1-\mathrm{MCP}$ was applied with a $\mathrm{CO}_{2}$ back-pack sprayer at $209 \mathrm{mg} \cdot \mathrm{L}^{-1}$ in 1\% summer oil (AFxRD-038; Rohm and Hass, Spring House, PA) and $0.05 \%$ silicone surfactant (Silwet L-77; Helena Chemical Co., Memphis, TN).

${ }^{y}$ Mean separation by Duncan's multiple range test at $P \leq 0.05$.

NS, ${ }^{* *}$ Not significant or significant at $P \leq 0.01$.

Table 3. Effect of 1-methylcyclopropene (1-MCP) application alone and in combination with naphthaleneacetic acid (NAA) at the 10$\mathrm{mm}$ stage on fruit set of 'Pioneer McIntosh'/M.9 apple.

\begin{tabular}{lccr}
\hline & $\begin{array}{c}\text { Bloom } \\
\text { Blossom clusters } \\
\text { (no./cm }{ }^{2} \text { LCSA) }\end{array}$ & \multicolumn{2}{c}{ Fruit set } \\
\cline { 3 - 4 } Treatment $^{\mathrm{z}}$ & 10.2 & $\begin{array}{c}\text { Fruit } \\
\left(\text { no. } / \mathrm{cm}^{2} \text { LCSA }\right)\end{array}$ & $(\%)$ \\
\hline Control & 10.2 & 10.6 & 108 \\
NAA & 10.2 & 7.3 & 89 \\
1-MCP & 9.7 & 8.4 & 89 \\
1-MCP + NAA & & 5.6 & 60 \\
Significance & NS & $*$ & $*$ \\
1-MCP & NS & $* *$ & $*$ \\
NAA & NS & NS & NS
\end{tabular}

z1-MCP was applied on 24 May with a $\mathrm{CO}_{2}$ back-pack sprayer at $209 \mathrm{mg} \cdot \mathrm{L}^{-1}$ in $1 \%$ summer oil (AFxRD-038; Rohm and Hass, Spring House, PA) and $0.05 \%$ silicone surfactant (Silwet L-77; Helena Chemical Co., Memphis, TN). NAA was applied at $6 \mathrm{mg} \cdot \mathrm{L}^{-1}$ as a dilute hand-gun spray on 25 May, $1 \mathrm{~d}$ after 1-MCP treatment.

${ }^{\mathrm{y}} \mathrm{LCSA}=$ limb cross-sectional area.

NS, **, ${ }^{*}$ Not significant or significant at $P \leq 0.01$ or 0.05 , respectively. 
previously measured 1-MCP was added to the tank, mixed for $30 \mathrm{~s}$, the top was placed on the sprayer, and the tank was then pressurized with $\mathrm{CO}_{2}$. The contents of the tank were sprayed on trees within $10 \mathrm{~min}$ of mixing. About $3 \mathrm{~L}$ of spray was applied to each tree.

On 17 May, 20 spurs were randomly selected on the periphery of each tree and tagged. Tagging was done at this time to preclude potential bias when fruit started to enlarge and before fruit size differences within the spur became apparent. The first set count was taken on 29 May when fruit were about $14 \mathrm{~mm}$ in diameter and it was possible to get a good indication of initial fruit set. The number of persisting fruit on each spur was counted on 29 May, 6 June, 13 June, and 14 Aug., and the average number of persisting fruit on each spur was calculated. At the end of June drop, in July, all persisting fruit were counted on the tagged portions of each of the two selected limbs and final fruit set was calculated. At the normal time of harvest on 10 Sept., 30 fruit were harvested from each tree. Fruit were weighed and red color was estimated to the nearest $10 \%$. A 10-apple subsample representative of the sample was selected. Flesh firmness was taken on two sides of each fruit using a pressure tester (EPT-1 Econic; Lake City Technical Products, Kelowna, BC, Canada). A juice sample was collected while doing the pressure test and soluble solids were determined using a hand-held refractometer (Fisher Scientific, Waltham, MA). Fruit were then cut at the equator and dipped in a solution containing $8.8 \mathrm{~g}$ of potassium iodide and $2.2 \mathrm{~g}$ of iodine crystals in $1 \mathrm{~L}$ of water for $1 \mathrm{~min}$. The starch distribution pattern was then judged on a scale of 1 to 8 (Blanpied and Silsby, 1992).

Expt. 2: 'Pioneer McIntosh'/M.9, Belchertown, MA. Twenty-four uniform trees were selected in 2007 in the block described above and they were similarly tagged, blossom clusters were counted, and bloom density was calculated. Trees were placed into six groups (replications) based upon similarity of blossom cluster density. Two trees in each replication received a spray of 1-MCP at $209 \mathrm{mg} \cdot \mathrm{L}^{-1}$ as described above on 24 May. One day later, one tree in each replication that was previously unsprayed received a spray containing $6 \mathrm{mg} \cdot \mathrm{L}^{-1} \mathrm{NAA}$ (AMVAC, Newport Beach, CA), while a second tree that was previously sprayed with 1-MCP also received a dilute spray of $6 \mathrm{mg} \cdot \mathrm{L}^{-1} \mathrm{NAA}$, leaving one tree that received a spray of 1-MCP only. Spray applications were done similarly to that described in Expt. 1. One tree per replication was unsprayed and served as the untreated control. At the end of June drop, all persisting fruit on the tagged portion of the two selected limbs per tree were counted and final set was calculated. At the normal harvest time in September, a 30-apple sample was randomly harvested from the perimeter of each tree and was subjected to the same evaluation that was described previously.
Expt. 3: 'Golden Delicious'/M.9, Winchester, VA. Sixteen uniform 'Golden Delicious' apple trees were selected from an orchard located at Alson H. Smith, Jr. Agricultural Research and Extension Center in Winchester, VA, and placed into four groups of four trees each. A randomized complete block design with four replications was used. Three replicates were used for gene expression analysis while all four replicates were used to determine the fruit abscission rate and the ethylene production of leaves and fruit. One tree from each block received one of the four treatments on 14 May 2007, when fruit size was about $10 \mathrm{~mm}$ in diameter. Treatments consisted of: 1) water, which served as the untreated control; 2) 1-MCP (Rohm and Haas) at $160 \mathrm{mg} \cdot \mathrm{L}^{-1}$; 3) NAA (AMVAC) at 15 $\mathrm{mg} \cdot \mathrm{L}^{-1}$; 4) 1 -MCP at $160 \mathrm{mg} \cdot \mathrm{L}^{-1}+\mathrm{NAA}$ at $15 \mathrm{mg} \cdot \mathrm{L}^{-1}$. All spray solutions contained $0.125 \%$ silicone surfactant (Silwet L-77) to improve dispersion. To minimize the loss of the active form of 1-MCP, 1-MCP formulation was mixed immediately before spraying. Solutions were applied to the canopy with a lowpressure hand-wand sprayer until runoff. NAA was applied about $1 \mathrm{~h}$ after the application of 1-MCP.
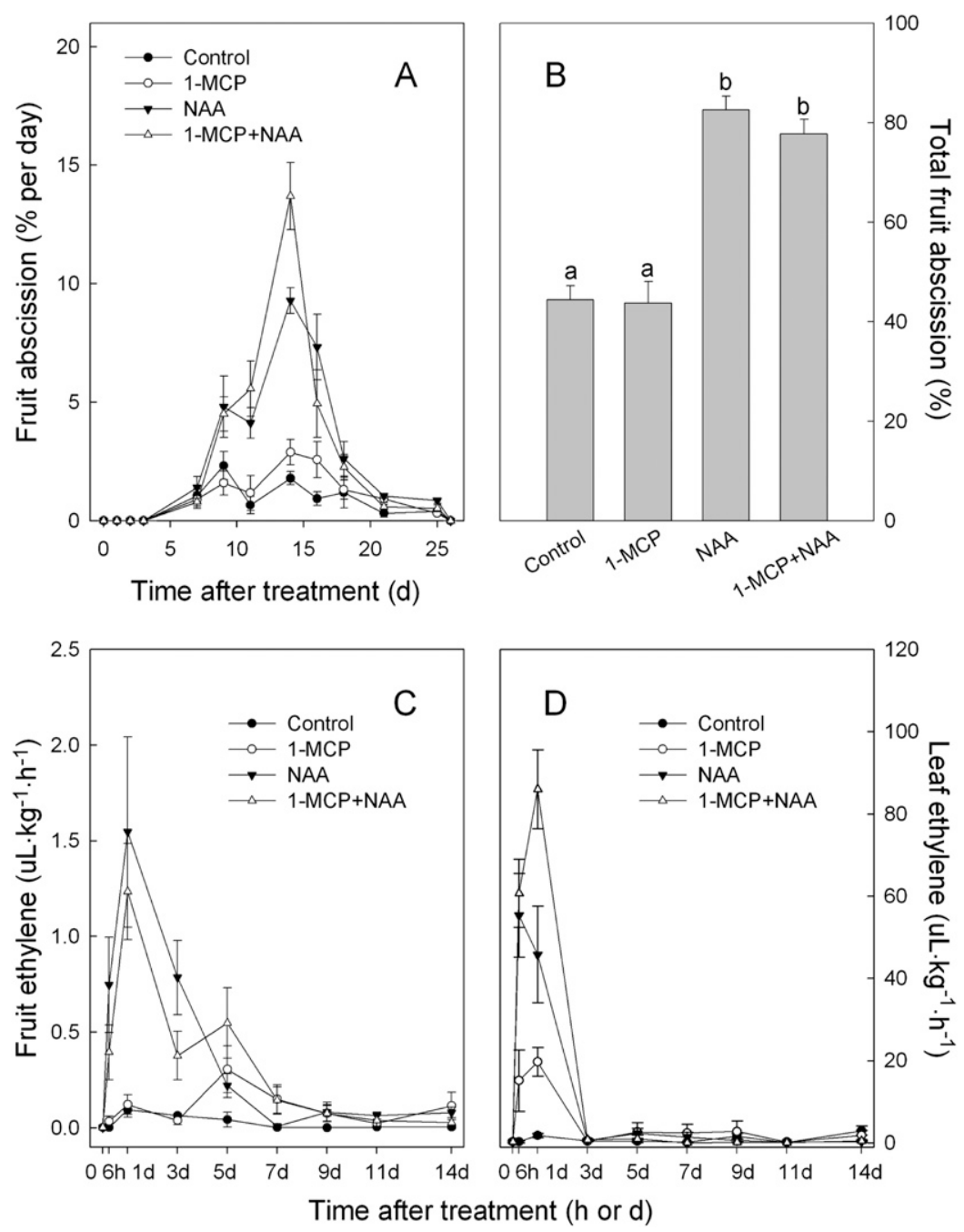

Fig. 1. Effects of 1-methylcyclopropene (1-MCP) and naphthaleneacetic acid (NAA) on fruit abscission pattern $(\mathbf{A})$, total fruit abscission $(\mathbf{B})$, fruit ethylene production $(\mathbf{C})$, and leaf ethylene production (D) in 'Golden Delicious' apple in 2007. Data are means \pm SE $(n=4)$. Different letters indicate significant differences among means according to Duncan's multiple range test at $P \leq$ 0.05 . 
About 150 young fruit were randomly collected from each tree of three replicate blocks 0 and $6 \mathrm{~h}$, and 1, 3, 5, and $7 \mathrm{~d}$ after treatment. The fruit samples were immediately separated into fruit cortex (FC) and fruit abscission zone (FAZ). For FC collection, skin and seeds were removed. FAZs were collected by cutting $1 \mathrm{~mm}$ at each side of the abscission fracture plane at the base of the pedicel. All samples were promptly frozen in liquid nitrogen and stored at $-80{ }^{\circ} \mathrm{C}$ for RNA extraction.

DETERMINATION OF FRUIT ABSCISSION AND ETHYLENE PRODUCTION OF FRUIT AND LEAVES. To determine the fruit abscission rate, two limbs on each tree were tagged. Fruit on tagged limbs were counted $0,1,2,3,7,9,11,14,16,18,21,25$, and $26 \mathrm{~d}$ after treatment. For ethylene production measurements, 15 fruit and 20 leaves were collected from each tree of four replicate blocks 0 and $6 \mathrm{~h}$ and $1,3,5,7,9,11$ and $14 \mathrm{~d}$ after treatment and were enclosed in a $100-\mathrm{mL}$ (for fruit) or 1000-mL (for leaves) container. After a 2-h incubation period, a 1-mL gas sample was withdrawn from the sealed container through the rubber septum affixed to the lid, and the ethylene concentration was measured with a gas chromatograph equipped with an activated alumina column and flame ionization detector (model 3700; Varian, Palo Alto, CA). The ethylene production was calculated and expressed as microliters of $\mathrm{C}_{2} \mathrm{H}_{4}$ per kilogram per hour.

TOTAL RNA EXTRACTION AND REAL-TIME QUANTITATIVE POLYMERASE CHAIN REACTION (QPCR). Total RNA was extracted from FAZ and FC tissues as described by Li and Yuan (2008), and was purified using a TURBO DNAfree $^{T M}$ Kit (Ambion, Austin, TX). RT-PCR was performed using primers that span an intron in $M d A C O$ to confirm that each RNA sample was free of genomic DNA contamination (Li and Yuan, 2008).

Purified total RNA (1 $\mu \mathrm{g})$ from each sample was used to synthesize cDNA in a $20-\mu \mathrm{L}$ reaction using the High-Capacity cDNA Reverse Transcription kit (Applied Biosystems, Fosters City, CA). Real-time qPCR was performed using the Power SYBR Green PCR Master Mix Kit (Applied Biosystems) on an Applied Biosystems 7500 Real-Time PCR System according to the manufacturer's instructions. Gene-specific primers were designed for non-conserved areas using Primer Expression 3.0 software and synthesized by Integrated DNA Technologies (Coralville, IA) (Zhu et al., 2008). Each reaction was run in triplicate in a $25-\mu \mathrm{L}$ reaction. Dissociation curves were generated and products were sequenced to determine the specificity of the amplification reaction. After validation tests, normalization to actin was performed and relative gene expression level was calculated using the $\Delta \Delta \mathrm{C}_{\mathrm{T}}$ method (Applied Biosystems, 2005).

Statistical analyses. In Expts. 1 and 3, the analyses were for a randomized complete block design, and included analysis of variance and Duncan's multiple range test. We applied GLM procedure in SAS system (SAS 9.1 for Windows; SAS Institute, Cary, NC) to analyze the statistical significance for gene expression by comparing the means of repli- cates at certain time points from different treatments $(P \leq 0.05)$. In Expt. 2, the statistical analysis was based on a $2 \times 2$ factorial with \pm NAA and \pm 1 -MCP experimental design, using Proc ANOVA in SAS.

\section{Results}

\section{Expt. 1: 'Pioneer McIntosh'/M.9, Belchertown, MA}

Regardless of the application time, 1-MCP did not affect the final fruit set (Table 1). This was true regardless of whether the set was expressed as fruit per square centimeter of LCSA or as a percentage set. Spurs evaluated on 29 May on trees treated with 1-MCP at petal fall (12 d prior) and at the $10-\mathrm{mm}$ stage ( $5 \mathrm{~d}$ prior) had a higher initial fruit set than the untreated control and spurs treated at bloom (Table 2). However, as June drop proceeded and subsequent counts were made, there was no difference in set among the treatments. Moreover, there were no differences in fruit weight, surface red color, soluble solids, starch rating, or flesh firmness (data not shown).

\section{Expt. 2: 'Pioneer McIntosh'/M.9, Belchertown, MA}

NAA treatment was previously shown to cause ethylene production linked with fruit drop (Curry, 1991; Zhu et al., 2008), and 1-MCP interferes with ethylene-dependent processes (Blankenship and Dole, 2003; Sisler and Serek, 1997; Watkins, 2006). Hence, we tested whether 1-MCP would interfere with the abscission induced by NAA. In contrast to our results for
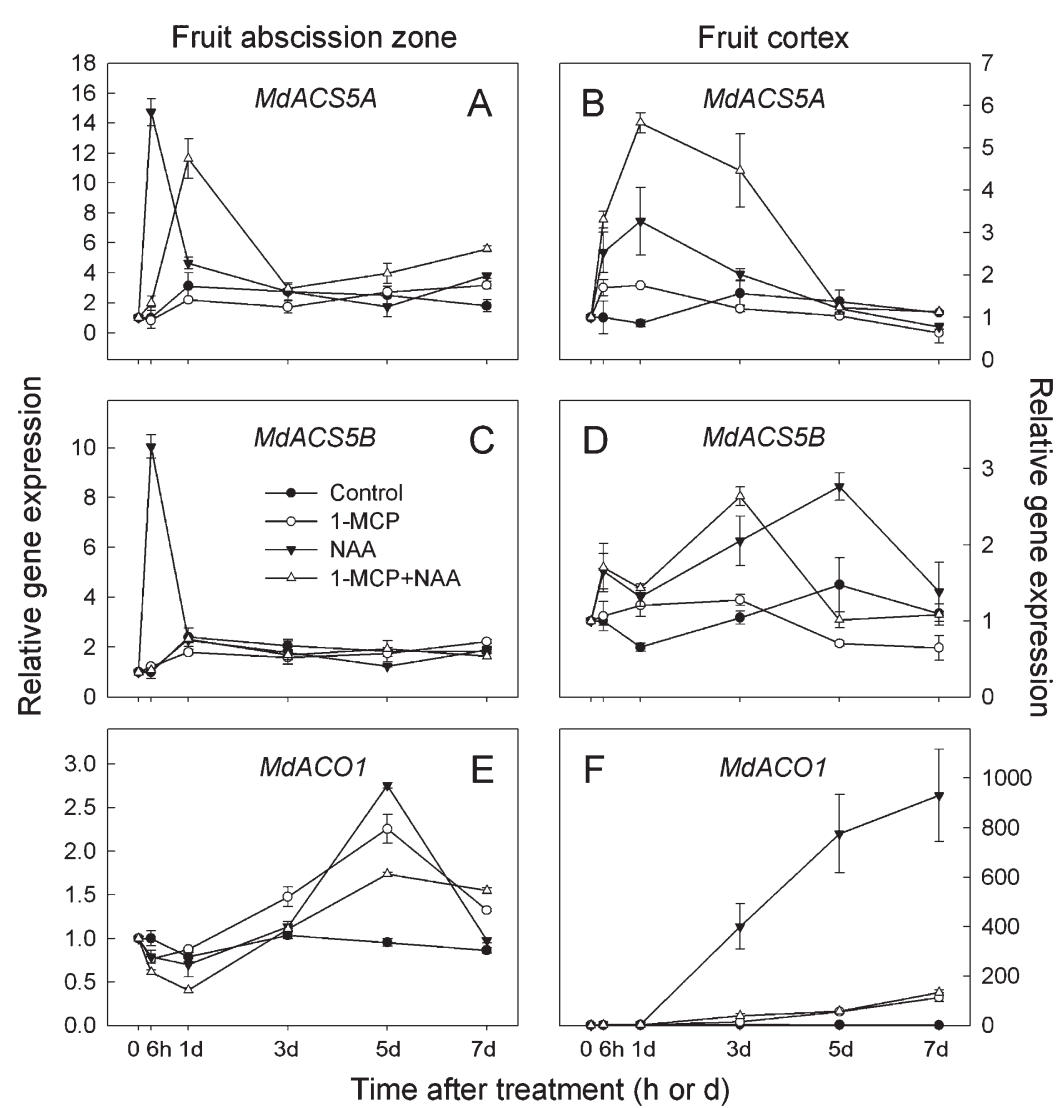

Fig. 2. Real-time quantitative PCR analysis of the expression of $M d A C S 5 A, M d A C S 5 B$, and $M d A C O 1$ in the fruit abscission zone $(\mathbf{A}, \mathbf{C}$, and $\mathbf{E})$ and the fruit cortex $(\mathbf{B}, \mathbf{D}$, and $\mathbf{F})$ from 'Golden Delicious' apple trees after application of 1-methylcyclopropene (1-MCP) and naphthaleneacetic acid (NAA). The levels of $M d A C S 5 A, M d A C S 5 B$, and $M d A C O 1$ transcripts were normalized using actin. Data are means $\pm \mathrm{SE}(\mathrm{n}=3)$. The values of MdACS5A, MdACS5B, and MdACO1 in the fruit abscission zone and the fruit cortex from control trees were arbitrarily set to 1 . 
Expt. 1 (Table 1), application of 1-MCP alone resulted in a significant $(P \leq 0.05)$ reduction in fruit set (Table 3$)$. As expected, NAA at $6 \mathrm{mg} \cdot \mathrm{L}^{-1}$ also caused significant thinning at $P \leq 0.01$ or 0.05 , expressed as LCSA or percentage set, respectively. Although a significant increase in fruit drop was caused by the 1-MCP + NAA treatment, there was no significant interaction between these growth regulators (Table 3). Even though 1-MCP caused some thinning in Expt. 2, most fruit quality characteristics were indistinguishable for control versus 1-MCP-treated fruit, as in Expt. 1 (data not shown).

\section{Expt. 3: 'Golden Delicious'/M.9, Winchester, VA}

EFFECTS OF 1-MCP AND NAA ON FRUIT ABSCISSION AND ETHYLENE PRODUCTION OF FRUIT AND LEAVES. The fruit abscission rate was significantly increased by NAA at $15 \mathrm{mg} \cdot \mathrm{L}^{-1}$ and peaked around $14 \mathrm{~d}$ after treatment. While $1-\mathrm{MCP}$ at $160 \mathrm{mg} \cdot \mathrm{L}^{-1}$ slightly enhanced the fruit abscission rate from 11 to $14 \mathrm{~d}$, it neither increased total fruit abscission nor reduced NAA-enhanced fruit abscission (Fig. 1, A and B), with the latter being consistent with results from Expt. 2. NAA markedly increased fruit ethylene production, which was detectable at $6 \mathrm{~h}$, peaked at $1 \mathrm{~d}$, and diminished to control levels by $7 \mathrm{~d}$. In contrast with NAA, 1-MCP-induced fruit ethylene increased between 3 and $5 \mathrm{~d}$, and fell to control levels by $9 \mathrm{~d}$ (Fig. 1C). The ethylene production of NAA-treated leaves peaked $6 \mathrm{~h}$ after treatment, while 1-MCP increased leaf ethylene production at $6 \mathrm{~h}$ and 1 $\mathrm{d}$ after treatment. By $3 \mathrm{~d}$, leaf ethylene production returned to control levels for all treatments (Fig. 1D).

EFFECT OF 1-MCP AND NAA ON EXPRESSION OF GENES ENCODING ENZYMES INVOLVED IN ETHYLENE BIOSYNTHESIS. The changes in gene expression discussed below were those exhibiting significant differences $(P \leq 0.05)$ relative to the control. 1-MCP alone had no effect on $M d A C S 5 A$ or $M d A C S 5 B$ expression in the FAZ, but enhanced the expression of these two genes in the FC at $1 \mathrm{~d}$ compared with the control (Fig. 2, A-D). In the FAZ, NAA significantly but transiently increased the expression of $M d A C S 5 A$ and $M d A C S 5 B$, i.e., the levels for both transcripts reached their observed maximum and returned to control levels within $1 \mathrm{~d}$. However, the expression of these two genes was more persistently enhanced by NAA in the FC, for at least an additional 2 d. Compared with the control, 1-MCP increased the expression of $M d A C O 1$, which was detectable at $3 \mathrm{~d}$ in the FAZ, and the $\mathrm{FC}$ and remained above control levels for the duration of the experiment (Fig. 2, E and F). NAA-dependent increases in $\mathrm{MdACO1}$ expression were noted at 5 and $3 \mathrm{~d}$ for the FAZ and FC samples, respectively. 1-MCP reduced the NAA-dependent increase in $M d A C O 1$ expression observed for the FAZ and completely eliminated the NAA-induced expression of $M d A C O 1$ in the FC.

EFFECTS OF 1-MCP AND NAA ON EXPRESSION OF GENES ENCODING ETHYLENE RECEPTORS AND THE ETHYLENE SIGNAL TRANSDUCTION KINASE CTR1. The level of MdETR1 transcript in the FAZ was unaffected by 1-MCP except at $5 \mathrm{~d}$, but was significantly enhanced in the $\mathrm{FC}$, maximally at $1 \mathrm{~d}$ and remaining above control levels thereafter (Fig. 3, A and B). 1-MCP inhibited MdETR $1 b$ and MdETR 2 expression in the FAZ and the FC at most time points, although an increase in the expression of both genes was noted in the FC at $7 \mathrm{~d}$ (Fig. 3, C-F). In general, the expression of all three MdETR genes was significantly increased by NAA in both tissues, whereas the effects of the 1-MCP + NAA treatment relative to NAA alone on the expression of the MdETR genes were variable, differing among genes and between tissues for each gene. However, one notable similarity was that 1-MCP treatment resulted in an early transient negative effect on NAA-induced expression of all three MdETR genes in the FAZ (Fig. 3, A, C, and E). Similarly, the expression of MdERS1 and MdERS2 in the FAZ was inhibited by 1-MCP at an early stage. 1-MCP also reduced the expression of these two genes in the FC, but only from 3 to 5 d (Fig. 4, A-D). NAA caused a sustained increase in the expression of MdERS1 and MdERS2 in the FC, whereas both genes exhibited a transient NAA-dependent increase in the FAZ. As was observed for the MdETR genes, the effects of the 1-MCP + NAA treatment relative to NAA alone on the expression of the $M d E R S$ genes were variable. MdCTR1 expression was not significantly affected by $1-\mathrm{MCP}$ in either tissue, but was continuously enhanced by NAA and 1-MCP + NAA in the FC (Fig. 4, E and F).

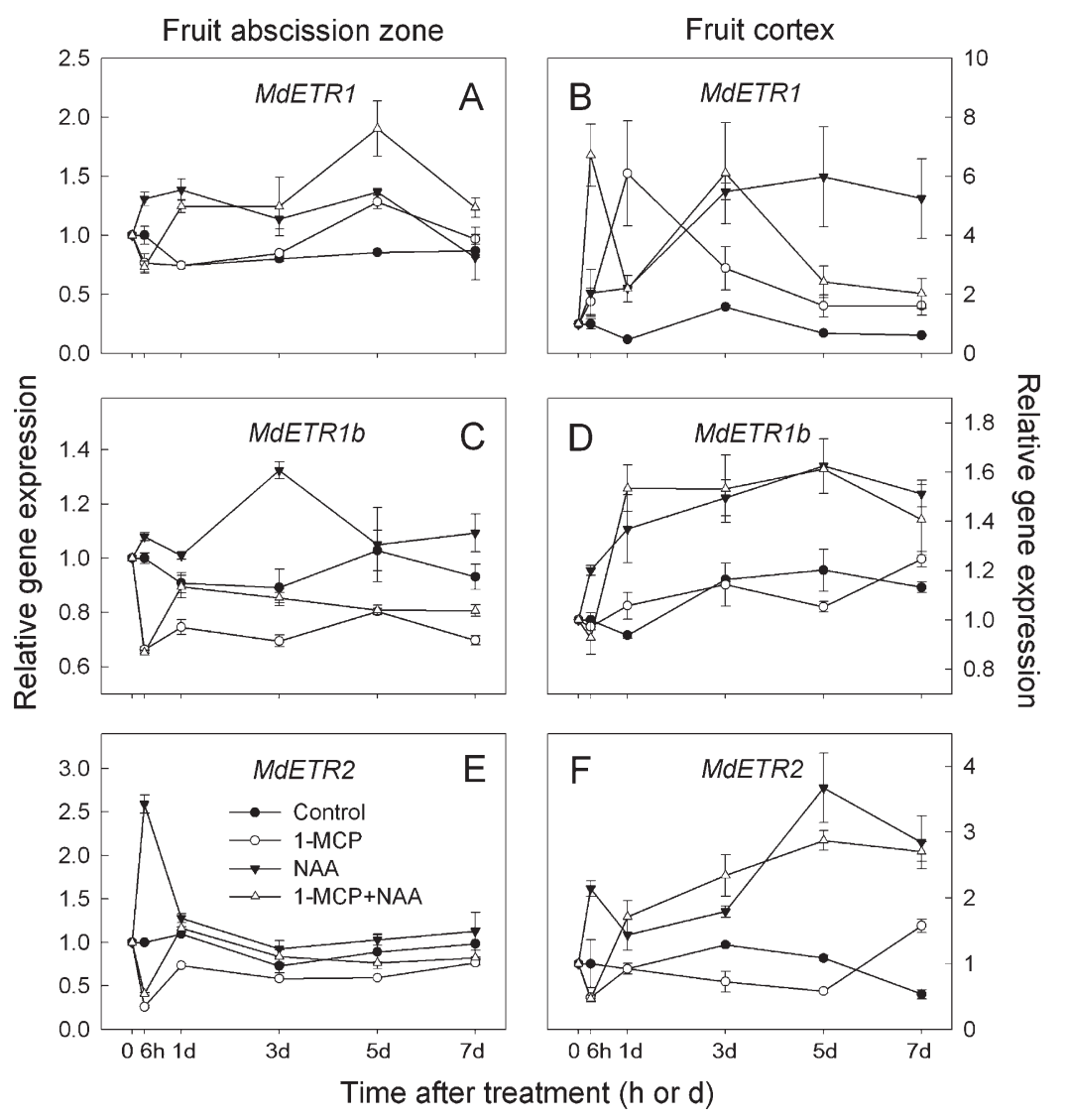

Fig. 3. Real-time quantitative PCR analysis of the expression of MdETR1, MdETR $1 b$, and MdETR2 in the fruit abscission zone $(\mathbf{A}, \mathbf{C}$, and $\mathbf{E})$ and the fruit cortex $(\mathbf{B}, \mathbf{D}$, and $\mathbf{F})$ from 'Golden Delicious' apple trees after application of 1-methylcyclopropene (1-MCP) and naphthaleneacetic acid (NAA). The levels of MdETR1, MdETR1b, and MdETR2 transcripts were normalized using actin. Data are means $\pm \mathrm{SE}(\mathrm{n}=3)$. The values of MdETR1, MdETR1b, and MdETR2 in the fruit abscission zone and the fruit cortex from control trees were arbitrarily set to 1 . 

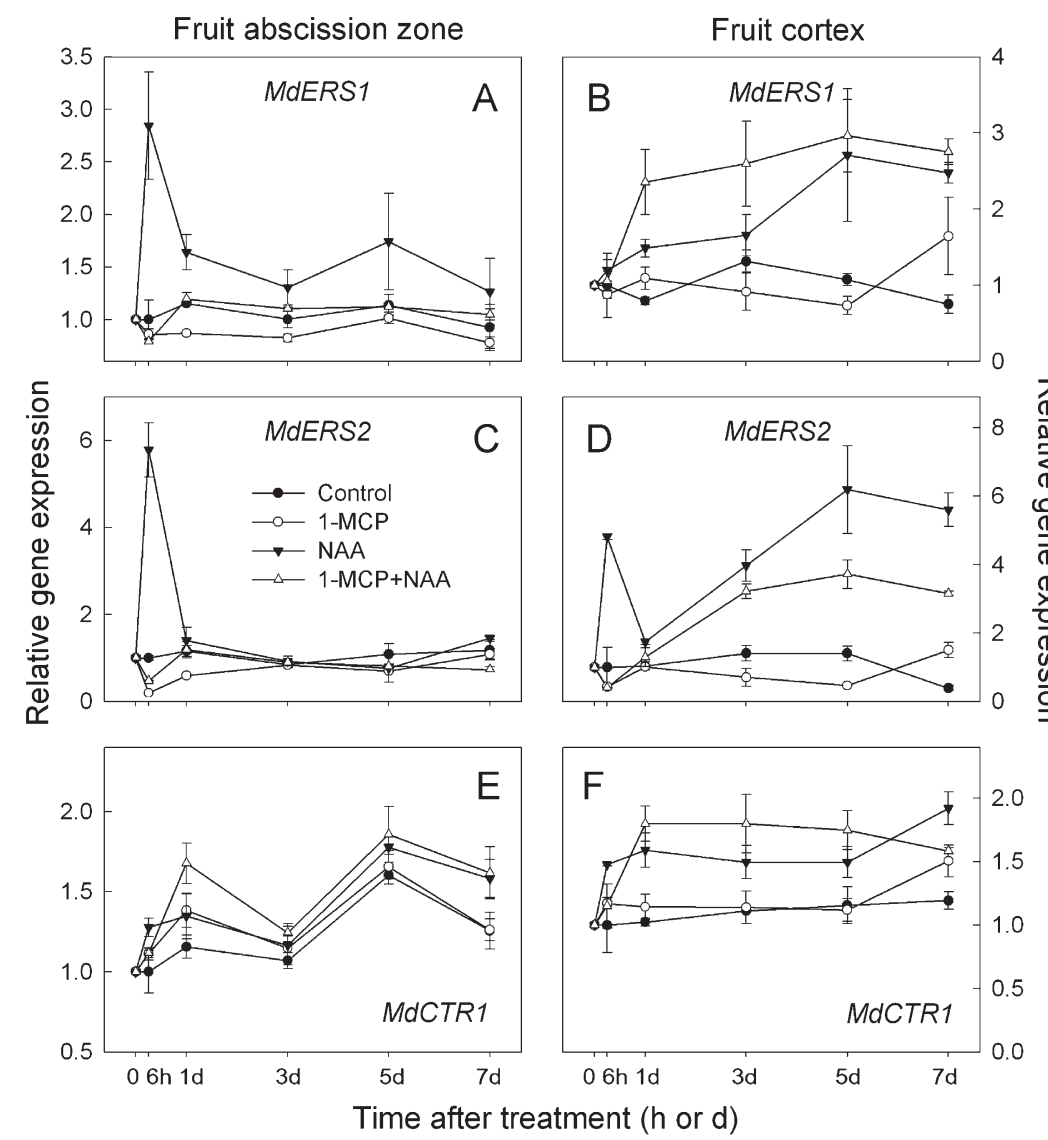

Fig. 4. Real-time quantitative PCR analysis of the expression of MdERS1, MdERS2, and MdCTR1 in the fruit abscission zone (A, C, and $\mathbf{E})$ and the fruit cortex $(\mathbf{B}, \mathbf{D}$, and $\mathbf{F})$ from 'Golden Delicious' apple trees after application of 1-methylcyclopropene (1-MCP) and naphthaleneacetic acid (NAA). The levels of MdERS1, MdERS2, and MdCTR1 transcripts were normalized using actin. Data are means $\pm \mathrm{SE}(\mathrm{n}=3)$. The values of MdERS1, MdERS2, and MdCTR1 in the fruit abscission zone and the fruit cortex from control trees were arbitrarily set to 1 .

EFFECTS OF 1-MCP AND NAA ON EXPRESSION OF GENES ENCODING ENZYMES INVOLVED IN CELL WALL DEGRADATION. $M d P G 2$ expression in the FAZ was enhanced by $1-\mathrm{MCP}$ and NAA maximally at $7 \mathrm{~d}$ after treatment (Fig. 5, A and B). In the $\mathrm{FC}$, treatment with 1-MCP + NAA mainly increased MdPG2 expression, while the application of 1-MCP or NAA had little effect. The expression of $\mathrm{MdCel1}$ was transiently enhanced by 1 MCP or NAA $6 \mathrm{~h}$ after treatment, but thereafter was significantly inhibited by either chemical relative to the control, except for an increase in the FC at $7 \mathrm{~d}$ caused by NAA (Fig. 5, C and D).

\section{Discussion}

Although the interactions between 1-MCP and ethylene physiology have been extensively studied in many fruit and vegetables, questions remain regarding the impact of 1-MCP on the molecular biology of the abscission of young apple fruit. To help address this deficiency and to gain a more detailed fundamental understanding of 1-MCP action, we measured the early and late responses of young apple fruit to a single application of 1-MCP, with and without NAA, focusing on abscission, ethylene production, and the expression of ethylene-related genes. Although a transient increase in fruit set following the application of 1-MCP at petal fall or the 10-mm stage indicated that an early application of 1-MCP has the potential to delay fruit drop, ulti-

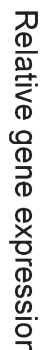

mately, 1-MCP applied to 'Pioneer McIntosh' and 'Golden Delicious' apple caused a decrease in fruit set in one experiment and had no effect on final fruit set in two others. These findings indicate that in contrast to its ability to delay preharvest fruit abscission and the ripening of mature fruit (Li and Yuan, 2008), 1-MCP, as used in this study, was not an inhibitor of the abscission of young fruit, and may in some cases promote abscission.

Two systems of ethylene regulation have been proposed to operate in higher plants (Barry et al., 2000; Lelievre et al., 1998; McMurchie, 1972). System I is ethylene auto-inhibitory and is responsible for the low level of ethylene during the preclimacteric stage, while system II is autocatalytic and has positive feedback regulation in which ethylene promotes its own synthesis during the climacteric ripening stage (Yang and Hoffman, 1984). Previous studies have consistently demonstrated that 1-MCP can effectively delay or decrease the ethylene production of climacteric fruit when they enter system II status (Bai et al., 2005; Hershkovitz et al., 2005; Wills and $\mathrm{Ku}$, 2002). On the other hand, 1-MCP does not inhibit and even causes transient ethylene stimulation in other systems, including citrus leaves (Zhong et al., 2001) and fruitlets (Katz et al., 2004) and some non-climacteric fruit and vegetables, including sweet cherry (Prunus avium L.), grapefruit (Citrus paradisi L.), chinese cabbage (Brassica campestris L.), and strawberry (Fragaria $\times$ ananassa Duch.) (Gong et al., 2002; Mullins et al., 2000; Porter et al., 2005; Tian et al., 1997). Similarly, in our study, 1-MCP appeared to suppress ethylene feedback inhibition; i.e., 1-MCP caused low-level (relative to the levels induced by NAA) transient increases of ethylene synthesis, although the leaf response appeared to be immediate, while the fruit response was markedly delayed (Fig. 1). The overall low levels of ethylene we observed in the young fruit are reminiscent of a system I-like characteristic and may partly explain why the impact of 1-MCP on the abscission of young fruit diverges from that reported for mature fruit in system II status.

1-MCP treatment led to a decrease in the transcript levels of most of the receptor genes in the FAZ. In contrast, NAA treatment increased the expression of most of the ethylene receptor genes in the FAZ and the $\mathrm{FC}$ and of MdCTR 1 in the $\mathrm{FC}$ only, perhaps reflecting a signal transduction negative feedback response to elevated fruit ethylene production in NAA-treated trees. These findings are generally consistent with previous reports of a positive correlation between abscission and increased expression of ethylene receptor genes in young apple fruit (Dal Cin et al., 2005; Zhu et al., 2008). In contrast, Yuan and $\mathrm{Li}$ (2008) found that despite an NAA-induced increase in the expression of genes encoding some ethylene receptors in mature 'Delicious' apple, preharvest fruit abscission was decreased. Such discrepancies in NAA effects could be related to different fruit developmental stages or other experimental factors differentiating these studies. It is also important to note that paradoxical relationships can exist between receptor 


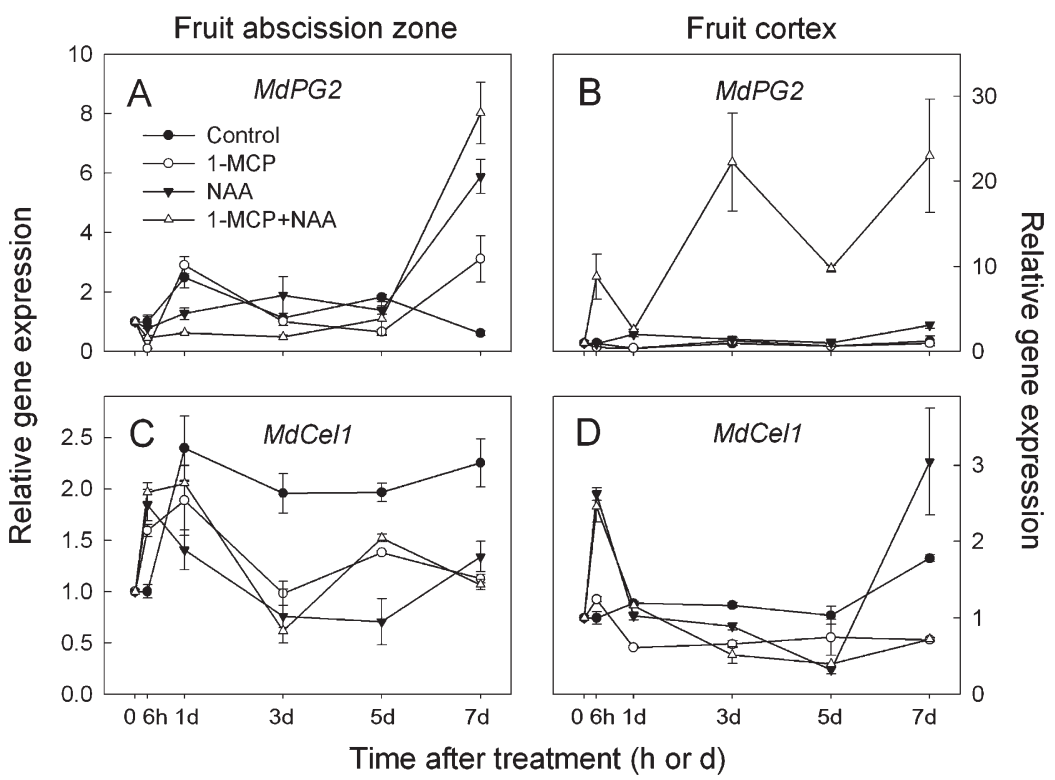

Fig. 5. Real-time quantitative PCR analysis of the expression of MdPG2 and MdCel1 in the fruit abscission zone (A and $\mathbf{C}$ ) and the fruit cortex (B and D) from 'Golden Delicious' apple trees after application of 1-methylcyclopropene (1-MCP) and naphthaleneacetic acid (NAA). The levels of $M d P G 2$ and $M d C e l 1$ transcripts were normalized using actin. Data are means \pm SE $(\mathrm{n}=3)$. The values of MdPG2 and MdCell in the fruit abscission zone and the fruit cortex from control trees were arbitrarily set to 1 .

mRNA levels and corresponding protein levels (Kevany et al., 2007), indicating that further work is required to determine the relationship between ethylene receptor mRNA and protein levels in young apple fruit in response to 1-MCP or NAA.

Some reports have indicated that an increase in $\mathrm{PG}$ and/or cellulase activities correlates with fruit abscission (Bonghi et al., 2000; Tonutti et al., 1995; Ward et al., 1999), but our study showed that the expression of MdCell, encoding $\beta-1,4-$ glucanase, was largely inhibited by NAA and 1-MCP in the FAZ, which was consistent with what we found in 'Delicious' apple (Zhu et al., 2008), suggesting that MdCell is not involved in the cell wall degradation induced by NAA. Zhu et al. (2008) did not detect the transcript for MdPGl in the FAZ or the FC from 'Golden Delicious' and 'Delicious' apple, which contrasts with other work showing that $M d P G 1$ was involved in apple fruit softening and that its expression was suppressed by 1-MCP and AVG treatment (Li and Yuan, 2008; Wakasa et al., 2006). The expression of MdPG2 in the FAZ was significantly induced by $1-\mathrm{MCP}$ and NAA just before the increase in the rate of fruit abscission (Fig. 1), in agreement with our previous work with NAA in 'Delicious' apple (Zhu et al., 2008), and was downregulated concomitant with an NAA-dependent reduction in preharvest fruit drop (Li and Yuan, 2008). Thus, while it is difficult to draw broad conclusions regarding these genes involved in cell wall hydrolysis, $M d P G 2$ appears to be the gene most strongly associated with abscission based on current information.

Unlike the ethylene synthesis inhibitor AVG that effectively inhibits NAA-induced young fruit abscission through decreased ethylene production (Zhu et al., 2008), 1-MCP had no effect or a small promotive effect on the abscission of young apple fruit (Tables 1-3). The differences in the efficacy of AVG versus $1-\mathrm{MCP}$ suggest that the ethylene signals can be more easily blocked at the biosynthesis level. However, once ethylene is generated, signaling may not be completely blocked at the receptor level by 1-MCP, due to the influence of changing receptor levels (Kevany et al., 2008), the competition between ethylene and 1-MCP for the ethylene-binding sites on receptors, and/or the changes in levels of ethylene and other ethylene pathway components affected by 1-MCP (Figs. 1-4). Moreover, while our previous work with AVG supports a model where ethylene synthesis is necessary for NAA-induced abscission of young apple fruit (Zhu et al., 2008), those experiments did not rule out a role for other AVG-sensitive, pyridoxal-5' -phosphate-dependent enzymes in the abscission process. This possibility, considered with the results presented here, suggests that in addition to the ethylenedependent pathway for abscission, a separate AVG-sensitive, 1-MCP-insensitive pathway may also promote the abscission of young apple fruit following NAA treatment. Alternatively, and more simply, the period of effectiveness of 1-MCP following a single application may not have sufficiently overlapped with the period of ethylene effectiveness.

In conclusion, we found that while 1-MCP may have some ability to transiently increase fruit set, it was not effective at increasing final fruit set. In this way, the effects of 1-MCP on the abscission of young fruit are distinct from those reported for mature fruit ( $\mathrm{Li}$ and Yuan, 2008; Yuan and Carbaugh, 2007; Yuan and Li, 2008). 1-MCP differentially regulated the expression of genes involved in ethylene biosynthesis and perception and cell wall degradation, but the expression patterns appeared to reflect a wide range of temporal and tissue-specific effects of 1MCP. NAA, as a synthetic auxin, effectively increased the abscission of young apple fruit, possibly through its ability to enhance the expression of nearly all of the ethylene-related genes investigated here in the FAZ and the FC. 1-MCP application did not reduce the level of NAA-induced abscission. Thus, the hypothesis that 1-MCP can inhibit the NAA-induced abscission of young fruit is not supported by this study. Having profiled the short- and long-term ethylene- and abscission-related responses of young fruit to a single application of 1-MCP alone and in combination with NAA, it will be interesting to identify through further research the precise mechanism by which NAA-induced fruit abscission is promoted in the presence of 1-MCP, and to determine the effects of multiple applications of 1-MCP in advance of young fruit abscission in apple.

\section{Literature Cited}

Alexander, L. and D. Grierson. 2002. Ethylene biosynthesis and action in tomato: A model for climacteric fruit ripening. J. Expt. Bot. 53: 2039-2055.

Applied Biosystems. 2005. Guide to performing relative quantitation of gene expression using real-time quantitative PCR. Applied Biosystems, Foster City, CA.

Bai, J.H., E.A. Baldwin, and K.L. Goodner. 2005. Response of four apple cultivars to 1-methylcyclopropene treatment and controlled atmosphere storage. HortScience 40:1534-1538.

Barry, C.S., M.I. Llop-Tous, and D. Grierson. 2000. The regulation of 1-aminocyclopropane-1-carboxylic acid synthase gene expression during the transition from system-1 to system-2 ethylene synthesis in tomato. Plant Physiol. 123:979-986. 
Blankenship, S.M. and J.M. Dole. 2003. 1-Methylcyclopropene: A review. Postharvest Biol. Technol. 28:1-25.

Blanpied, G.D. and K.J. Silsby. 1992. Prediction of harvest date windows for apples. Cornell Coop. Ext. Bul. 221.

Bleecker, A.B. 1999. Ethylene perception and signaling: An evolutionary perspective. Trends Plant Sci. 4:269-274.

Bonghi, C., P. Tonutti, and A. Ramina. 2000. Biochemical and molecular aspects of fruitlet abscission. Plant Growth Regulat. 31: 35-42.

Chang, C.R. and A.B. Bleecker. 2004. Ethylene biology. More than a gas. Plant Physiol. 136:2895-2899.

Chen, Y.F., N. Etheridge, and G.E. Schaller. 2005. Ethylene signal transduction. Ann. Bot. (Lond.) 95:901-915.

Curry, E.A. 1991. NAA-induced ethylene and ACC in 'Delicious' spur tissues: Changes with temperature and time. J. Amer. Soc. Hort. Sci. 116:846-850.

Dal Cin, V., M. Danesin, A. Boschetti, A. Dorigoni, and A. Ramina. 2005. Ethylene biosynthesis and perception in apple fruitlet abscission (Malus domestica L. Borkh). J. Expt. Bot. 56:2995-3005.

Fan, X.T., S.M. Blankenship, and J.P. Mattheis. 1999. 1-Methylcyclopropene inhibits apple ripening. J. Amer. Soc. Hort. Sci. 124:690-695.

Gong, Y.P., X.T. Fan, and J.P. Mattheis. 2002. Responses of 'Bing' and 'Rainier' sweet cherries to ethylene and 1-methylcyclopropene. J. Amer. Soc. Hort. Sci. 127:831-835.

Hershkovitz, V., S.I. Saguy, and E. Pesis. 2005. Postharvest application of 1-MCP to improve the quality of various avocado cultivars. Postharvest Biol. Technol. 37:252-264.

Huai, Q., Y.H. Xia, Y.Q. Chen, B. Callahan, N. Li, and H.M. Ke. 2001. Crystal structure of 1-aminocyclopropane-1-carboxylate (ACC) synthase in complex with aminoethoxyvinylglycine and pyridoxal$5^{\prime}$-phosphate provide new insight into catalytic mechanisms. J. Biol. Chem. 276:38210-38216.

Jeong, J., D.J. Huber, and S.A. Sargent. 2002. Influence of 1methylcyclopropene (1-MCP) on ripening and cell-wall matrix polysaccharides of avocado (Persea americana) fruit. Postharvest Biol. Technol. 25:241-256.

Jiang, Y. and D. Joyce. 2000. Effects of 1-methylcyclopropene alone and in combination with polyethylene bags on the postharvest life of mango fruit. Ann. Appl. Biol. 137:321-327.

Katz, E., P.M. Lagunes, J. Riov, D. Weiss, and E.E. Goldschmidt. 2004. Molecular and physiological evidence suggests the existence of a system II-like pathway of ethylene production in non-climacteric citrus fruit. Planta 219:243-252.

Kevany, B.M., M.G. Taylor, and H.J. Klee. 2008. Fruit-specific suppression of the ethylene receptor LeETR4 results in earlyripening tomato fruit. Plant Biotechnol. J. 6:295-300.

Kevany, B.M., D.M. Tieman, M.G. Taylor, V. Dal Cin, and H.J. Klee. 2007. Ethylene receptor degradation controls the timing of ripening in tomato fruit. Plant J. 51:458-467.

Kluge, R.A. and A.P. Jacomino. 2002. Shelf life of peaches treated with 1-methylcyclopropene. Scientia Agricola 59:69-72.

Lelievre, J.M., A. Latche, B. Jones, M. Bouzayen, and J.C. Pech. 1998. Ethylene and fruit ripening. Physiol. Plant. 101:727-739.

Li, J. and R. Yuan. 2008. NAA and ethylene regulate expression of genes related to ethylene biosynthesis, perception and cell wall degradation during fruit abscission and ripening in 'Delicious' apples. J. Plant Growth Regul. 27:283-295.
McArtney, S.J. 2002. Ethylene evolution from detached apple spurs in response to chemical thinners. HortScience 37:662-665.

McMurchie, E.J. 1972. Treatment of fruit with propylene gives information about the biogenesis of ethylene. Nature 237:235-236.

Mullins, E.D., T.G. McCollum, and R.E. McDonald. 2000. Consequences on ethylene metabolism of inactivating the ethylene receptor sites in diseased non-climacteric fruit. Postharvest Biol. Technol. 19:155-164.

Porter, K.L., G. Collins, and A. Klieber. 2005. 1-MCP does not improve the shelf-life of chinese cabbage. J. Sci. Food Agr. 85:293296.

Sisler, E.C. and M. Serek. 1997. Inhibitors of ethylene responses in plants at the receptor level: Recent developments. Physiol. Plant. 100: 577-582.

Tian, M.S., Y.P. Gong, and A.D. Bauchot. 1997. Ethylene biosynthesis and respiration in strawberry fruit treated with diazocyclopentadiene and IAA. Plant Growth Regulat. 23:195-200.

Tonutti, P., L.G. Cass, and R.E. Christoffersen. 1995. The expression of cellulase gene family members during induced avocado fruit abscission and ripening. Plant Cell Environ. 18:709-713.

Wakasa, Y., H. Kudo, R. Ishikawa, S. Akada, M. Senda, M. Niizeki, and T. Harada. 2006. Low expression of an endopolygalacturonase gene in apple fruit with long-term storage potential. Postharvest Biol. Technol. 39:193-198.

Walsh, C.S., H.J. Swartz, and L.J. Edgerton. 1979. Ethylene evolution in apple following post-bloom thinning sprays. HortScience 14:704706

Ward, D.L., E.P. Beers, R.E. Byers, and R.P. Marini. 1999. Cutting apple fruits induces cellulose activity in the abscission zone. HortScience 34:601-603.

Watkins, C.B. 2006. The use of 1-methylcyclopropene (1-MCP) on fruits and vegetables. Biotechnol. Adv. 24:389-409.

Williams, R.R. and V.A. Flook. 1980. The mode of action of the hormone apple fruit-setting mixture PP-341B applied to 'Cox's Orange Pippin'. J. Hort. Sci. 55:275-277.

Wills, R.B.H. and V.V.V. Ku. 2002. Use of 1-MCP to extend the time to ripen of green tomatoes and postharvest life of ripe tomatoes. Postharvest Biol. Technol. 26:85-90.

Yang, S.F. and N.E. Hoffman. 1984. Ethylene biosynthesis and its regulation in higher plants. Annu. Rev. Plant Physiol. 35:155-189.

Yuan, R. 2007. Effects of temperature on fruit thinning with ethephon in 'Golden Delicious' apples. Sci. Hort. 113:8-12.

Yuan, R. and D.H. Carbaugh. 2007. Effect of NAA, AVG, and 1-MCP on ethylene biosynthesis, preharvest fruit drop, fruit maturity, and quality of 'Golden Supreme' and 'Golden Delicious' apples. HortScience 42:101-105.

Yuan, R. and J. Li. 2008. Effects of sprayable 1-MCP, AVG and NAA on ethylene biosynthesis, preharvest fruit drop, fruit maturity, and quality of 'Delicious' apples. HortScience 43:1454-1460.

Zhong, G.Y., M. Huberman, X.Q. Feng, E.C. Sisler, D. Holland, and R. Goren. 2001. Effect of 1-methylcyclopropene on ethylene-induced abscission in citrus. Physiol. Plant. 113:134-141.

Zhu, H., E.P. Beers, and R. Yuan. 2008. Aminoethoxyvinylglycine inhibits fruit abscission induced by naphthaleneacetic acid and associated relationships with expression of genes for ethylene biosynthesis, perception, and cell wall degradation in 'Delicious' apples. J. Amer. Soc. Hort. Sci. 133:727-734. 